\title{
Entrepreneurial Awareness among High School Learners: Case Study of Buffalo City Metropolitan Municipality
}

\author{
Mishi Syden \\ University of Fort Hare, Department of Economics \\ mishi.syden@gamil.com / smishi@ufh.ac.za
}

Shaw Gordon K.

University of Fort Hare, UFH/SANLAM Chair in Entrepreneurship

\section{Doi:10.5901/mjss.2014.v5n8p146}

\begin{abstract}
Much has been written and said about the importance of entrepreneurship being taught as an academic course; however action is far from being visible. The maxim: catch them young, forms the crux of this papers argument. This paper is to an extent motivated, among other things by some of the GEW (2009) Report's Key Discussion Points namely: South Africa's entrepreneurial activity is improving but still lags behind; Entrepreneurial skills are severely lacking; and that corporate careers are still more desirable in South African Society. This study aimed to discover to what extent students acknowledge entrepreneurship as a career choice. Descriptive research in this study established the Entrepreneurial awareness among high school leavers in Buffalo City Metropolitan Municipality. Teachers are playing a prominent role in disseminating information about entrepreneurship to high school learners. This is a great testimony to the role of hidden curricula. It is crucial then that teachers in the meantime (while entrepreneurship education is to be formalised) receive entrepreneurship education so that they will be able to inform well the learners. This applies to parents who also engage high school students in entrepreneurship discussions.
\end{abstract}

Keywords: entrepreneurship, education, high school learners, economy, hidden curricula

\section{Introduction}

To date much has been written and said about the importance of entrepreneurship being taught as an academic course, however action is far from being visible.

Richard Strudwick ${ }^{1}$ once argued that there is need to encourage an entrepreneurial approach to life, which recognises the talents of all. In other words, he added, the enterprise net needs to be cast as wide as possible and there is need of as many channels to reach these people as possible. This entails reaching out to even high schools students, which by virtue of their age and level of education are starting considering various career options. The author further argued that enterprise education needs to create awareness within the school system so that an entrepreneurial approach to life and awareness of self-employment as a career option are already instilled in all school leavers.

The approach may differ from system to system, but, this study would like to argue, the concept is undoubtedly appealing, more especially to an economy with low entrepreneurial rate as South Africa, (Global Entrepreneurship Week (GEW), 2009). The maxim: catch them young, forms the crux of our argument. It can be argued that the earlier people are exposed to entrepreneurship, the more likely they will become entrepreneurs in some form during their lives (WEF, 2009). Furthermore, researchers have suggested that education and training for entrepreneurship should positively influence actions by enhancing the skills required to start and grow a venture (Honig, 2004; Summit Consulting, 2009).

Schools (as a system) and teachers have a crucial role to play in encouraging entrepreneurship among high school students. Entrepreneurship may be formally included in the curricula or be informally included (hidden curricula concept) through motivation and positive referral by educators. Hope can be on 'referral' education if entrepreneurship has not been formally included in the high school curricula. Teachers therefore will have a significant role, since what they say about entrepreneurship becomes authoritative among high school learners, working to either encourage or discourage its

1 Richard Strudwick has worked in enterprise education in the UK and internationally since 2002. http://www.director.co.uk/ONLINE /2010/09_10_enterprise_UK_education.html 
selection as a career choice.

It is thus imperative to analyse if entrepreneurial education is present in high schools and if the learners are content with the material to the extent of being confident to choose entrepreneurship as a career path.

\section{Problem Statement}

This paper is to an extent motivated, among other things by some of the GEW (2009) Report's Key Discussion Points namely:

\subsection{South Africa's entrepreneurial activity is improving but still lags behind}

The most widely used measure of entrepreneurship is the TEA (Total Entrepreneurial Activity) or 'early stage entrepreneurial activity' Index. It measures entrepreneurial activity by looking at the percentage of the active population, people between 25 and 64, who are entrepreneurs in any given country. South Africa's TEA in 2008 stood at 7,8\%, which is greater than what it was in $2006(5 \%)$ but still lower than India-Brazil $(11,5 \%-12 \%)$, Colombia $(24,5 \%)$, Mexico $(13,1 \%)$ and even the United States $(10,8 \%)$. In 2009, following the economic crisis, the level of early-stage entrepreneurial activity in South Africa dropped again to just over $5 \%$. Within South Africa, sharp differences remain within demographic groups with Indians and Whites having the most entrepreneurs (1,6:1 and 1,7:1 respectively compared to the general population), while Blacks and Coloureds have fewer entrepreneurs (0,9:1 and 1,2:1 respectively compared to the general population).

\subsection{Entrepreneurial skills are severely lacking}

Both formal (primary to tertiary education) and informal (home and social networks) educational structures do not impart entrepreneurial skills in South Africa.

\subsection{Corporate careers are still more desirable in South African Society}

South African society still, by and large, honours mathematics and science academic achievement and corporate careers. Social science academics and entrepreneurial careers are not considered to be the "golden path" and as such do not always attract the best and the brightest. Such values and behaviours need to be confronted and changed at homes, in schools, and at universities. They restrain entrepreneurial activity and entrench stereotypes about the kinds of backgrounds entrepreneurs should or should not have. The reality, of course, is very different from the perception.

From the GEW (2009) report, South Africa has been reported to have a very low entrepreneurship rate as measured by the TEA index compared to similar emerging market economies like Brazil. This is a great cause for concern, given the adamant high unemployment rate witnessed in South Africa. Entrepreneurial skills may necessitate small business development, culminating in improved job creation within the economy. The main challenge is that entrepreneurship had not been formally introduced in the education system, leading to severe lack of entrepreneurial skills. Since entrepreneurship education had not been formally included in high school curricula: is the 'talk' of it by educators, various workshops/ road shows and projects by various organisations yielding any impact? The hidden curricula concept could be the hope. Under this concept, there is a general belief that pupils are told much else besides school subjects- are socialised into norms, values, beliefs, or getting them absorb the ideology of wider capitalist society, for example. High school is a career turning point for many, thus a high yielding learning phase as many thoughtfully consider their next step. Can this learning phase be effectively utilised for effective entrepreneurship awareness? The next and vital follow up question could be: are entrepreneurship awareness campaigns informative enough, would it be different if entrepreneurship was taught as a structured course in these high schools? From the current discourse corporate careers are still highly regarded over entrepreneurship. This is unsurprising given the dire entrepreneurial skills exchange culture in South Africa.

From this it follows: entrepreneurial activity in South Africa is very low, the South African education system have not yet formally institutionalised entrepreneurship education and thus entrepreneurship has not yet got a sizeable nod as alternative career path. If entrepreneurial activity is so low yet so crucial for economic growth, to what extent is entrepreneurship education available in high schools, given the status quo, vis-à-vis formalisation of entrepreneurial education? 


\section{Study purpose and objectives}

This study aims to discover to what extent students acknowledge entrepreneurship as a career choice. Specifically the study will seek to find out if:

a. Entrepreneurship is taught in high schools;

b. Teachers, refer to/approach entrepreneurship with enthusiasm for job creation or as a substitute for students not obtaining employment after leaving school? Testing if entrepreneurship is included in the hidden curriculum.

c. Students will be more inclined to become entrepreneurs if entrepreneurship was taught at school?

d. Students feel entrepreneurship must be included in high school curriculum.

\section{Justification of the study}

Considering the results from the GEW report, with a pathetic TEA ratio for South Africa, entrepreneurship education need to be take seriously. There is need to understand the level at which entrepreneurship should start to be formalised so as to inspire confidence to the South African population towards entrepreneurial activity. The outcome of the study will feed to policy formulation focused on entrepreneurship development and curriculum renewal.

Entrepreneurship will be able to assist in much needed job creation. In response to the rapidly changing national landscape, not only of employment but more generally of economic growth and job creation, entrepreneurship is being increasingly emphasized as a critical resource for negotiating and mastering this new terrain, (Kourilsky, 1995).

According to the GEM (2008) report, the impact of entrepreneurship education and training on individual attitudes, actions and ambitions is of particular interest to policy makers, educators and practitioners. It is generally believed that individuals who perceive they have the skills and knowledge to start a business are more likely to do so. It is thus imperative to assess the presence or absence of entrepreneurship education in high schools, give this perceived impact.

\section{Literature review}

Entrepreneurship lies at the heart of the free market system (Davies, 2001:32) and it has the ability to mobilise and coordinate production factors in such a way as to create profits. Entrepreneurs are important and have a quick reaction on opportunities which are left out or missed by larger and more bureaucratic business organisations. The concept is not only associated with small scale enterprise it is also known to have positive spin offs in government, public and cooperative enterprises (Sathorar, 2009: 44). The world had recently suffered from economic recession during 2008-2009 period, high unemployment rates and fluctuations in international trade cycle which hit levels never experienced since World War II. This increased attention paid by policy makers and political decision makers to the potential role of entrepreneurs as a possible solution to curbing rising unemployment and as a recipe for economic prosperity (Garavan and O'Cinneide, 1994: 3).

Niyonkuru (2005) carried out situational analysis of entrepreneurship education at tertiary institutions in Rwanda: the results reveal that the development of entrepreneurship education at higher education institutions in Rwanda is hampered by the lack of support mechanisms, the theoretical orientation of entrepreneurship curriculum and the resort to traditional methods of teaching and assessing entrepreneurship classes. Even though in this study, focus is on entrepreneurship in high schools, the conclusions act as a guideline for promoting entrepreneurship education. Niyonkuru's analysis focused on the educators rather the learners. Assessing from learners is more relevant.

In the past decade, entrepreneurial development has seen an increase in interests (Higgins and Elliot 2010:347). However, some serious questions have been raised on the current methods of entrepreneurship development and education and what should be the most appropriate approach to development and education. Surprisingly, Hindle (2007) refers entrepreneurship development and education as a field of study that lacks legitimacy as a source of true value in the context of the community. However, Brijlal et al (2007:614) defined entrepreneurship education as the structure for formal conveyance of entrepreneurial competencies, which in turn refers to concepts, skills and mental awareness used by individuals during the process of starting and developing their growth oriented ventures. These ventures play a significant role in utilising resources, rewarding the owners and creating job opportunities for the rest of the community.

Furthermore, Mauchi et al (2011) provided the definition of entrepreneurship opportunities and identified the necessary knowledge, skills and attitudes to act on such opportunities. Therefore, entrepreneurship education can be seen as a process of imparting learners with entrepreneurial knowledge, skills and attitudes through a formal structured instruction. At present, scholars and researchers in the field are currently challenging one another to the question: what is 
the most effective approach to educate about entrepreneurship, (Higgins and Elliot 2010:347). This question applies squarely to the South African context as well.

Under education, the literature has used entrepreneurship, enterprise, and small business education interchangeably (Alberti, Sciascia, and Poli, 2004; Garavan and O'Cinneide, 1994) thus attesting the confusion that surrounds these terms. For example, the term enterprise education is preferred in the United Kingdom and Ireland, while entrepreneurship education is commonly used in the USA and Canada. Referring to the distinction made by Garavan and O'Cinneide (1994:4), "...enterprise education has the objective to develop enterprising people and inculcate an attitude of self-reliance using appropriate learning, while entrepreneurship education aims directly at stimulating entrepreneurship which may be defined as independent small business ownership or the development of opportunity seeking-managers within companies". As for small business education, the aim is at increasing the number of people who are knowledgeable about small business to consider it as a career option. These definitions remain the source of confusion in structuring academic course. In this study reference is made to entrepreneurial education, which takes an operational definition that draws from the above definitions. Entrepreneurship education is aimed at stimulating the desire to start own business through imparting the skills of identifying opportunities and having the stamina to successfully execute a business model.

The importance of entrepreneurship and the fact that entrepreneurship education is a vehicle that enhances entrepreneurial activities was emphasised in The World Economic Forum's Global Education Initiatives (WEFORUM), 2009 report that called for transformation of education systems to stimulate economic growth. The report highlights the importance of entrepreneurship education for developing the skills, attitudes and behaviours necessary to create jobs, generate economic growth, advance human welfare and stimulate innovation to address global challenges (WEFORUM, 2009). Expanding the level of entrepreneurial activity within all nations is an increasing important political and economic priority, especially for developing countries.

There is no single model identified as a benchmark for entrepreneurship education and training, and it is still not clear how entrepreneurship should best be introduced, (OECD, 2005). Should young people learn how to start their own business or should they be taught willingness to change and take risks or other elements such as personal characteristics associated with entrepreneurship? The United States which has a relatively long history in this field has tended to favour the first approach. According to (OECD, 2005) children are taught self-employment as an alternative career as well as the positive effects of entrepreneurship. Other countries may tend to prefer the second approach, for example Sweden which launched a three year national programme for entrepreneurship in 2002 with the aim to improve the entrepreneurial startups. Finland too, has adopted the last type of approach, aiming at developing an attitude of entrepreneurship involving flexibility, creativity, capability of taking risks and initiative. Finland's Entrepreneurship project gave rise to a new far reaching curriculum, starting in 2004, requiring primary schools to incorporate entrepreneurship and including a thematic entity "participating citizenship and entrepreneurship" for upper secondary schools. However, most OECD countries try a combination of both approaches.

Entrepreneurs are important in the economy of any country; (Gouws, 1998) cites four basic reasons. Firstly, entrepreneurs create job opportunities, most of the South African youths are jobless, and there is high unemployment rate among the youths due to lake of skills and experience. By having many entrepreneurs in the economy this will enhance employment opportunity since there will be an increase in demand of the labour force. Secondly, entrepreneurs initiate the production process, that is, there will be the need for production on a new line of business which was not available. Thirdly, without entrepreneurs natural resources remain not extracted and undeveloped. Lastly, entrepreneurship serves as a catalyst that generates wealth and a higher standard of living. Therefore, a society would greatly benefit from the enhancement of entrepreneurship talent since it impacts positively on economic growth and wellbeing (Kent 1990:34). If South Africa could succeed in having many entrepreneurs, then most of the challenges faced now will be addressed.

Some people are indeed born with ambition, motivation, and willingness to take risks, but encounter barriers that erode this spirit of adventure. In this instance, entrepreneurship education needs to remove some of the barriers that have eroded self-confidence and self-esteem and along with them the spirit of adventure the willingness to take initiative and risk, (that is, the spirit of entrepreneurship). Unfortunately, not all people have the desire, ability or opportunity to become successful entrepreneurs. However, Rayne (1983:238) argues that many of those who lack the ability can be helped through education and training. Although most qualities are to some extent innate, there are those that seem to lend themselves to be enhanced through education, training and practice. More so analytical and computational skills can be taught.

The major objectives of enterprise education are to develop enterprising people and inculcate an attitude of selfreliance using appropriate learning processes. Mwangi (2011:87), cited objectives of entrepreneurship education and 
training programme as to: acquire knowledge germane to entrepreneurship; acquire skills in the use of techniques in the analysis of business situations and in the synthesis of action plans; identify and stimulate entrepreneurial drive talent and skills. Also to undo the risk-adverse bias of many analytical technical techniques, to develop empathy and support for all aspects of entrepreneurship, to devise attitudes towards change, to encourage new start-ups and other entrepreneurial ventures. Thomas and Barra, (1994) argues that these objectives underscore the fact that entrepreneurship education should reflect carefully on acquisition of business skills and ways of enhancing the probability of success. The objectives of entrepreneurship education are mainly focused on starting a business and following sustainability of the business. Thus, entrepreneurs are characterised by innovative behaviour and employ strategic skills and management practices with the aim of making profit and growth.

\section{Relevant Education}

Since independence from colonial rule; countries in the Eastern, Central and Southern African regions have made innovative attempts to restructure their education and training systems in order to keep pace with the changing needs of their respective countries. King (1989:2) argues that the challenge remains that the bulk of primary and secondary school leavers cannot readily find employment as was the case during the colonial era.

The challenge that is facing South Africa and indeed the entire Southern African region is to break away from education for dependency to educational for independence. It means that the goal of education must shift from education for employment to education for self-employment (or education for entrepreneurship). Mabunda (2002) argues that failure of an education system to meet this challenge will render it not only irreverent to the needs of its target population, but also of very little use to the socio-economic development of individual countries and to the region as a whole. The call for a relevant educational system is therefore a serious and urgent one as we enter the $21^{\text {st }}$ century.

On the other hand, it is of importance for entrepreneurship programmes to be differentiated between inculcating attitudes among school leavers in general and providing entrepreneurship training for those who have the interest and aptitude to engage in self-employment. Gunatilaka et al (2010) argued that studies show that youths who have no intention of engaging in self-employment or starting businesses are selected for entrepreneurship training programs, which are primarily designed for those who do wish to become entrepreneurs. While all youth need to have enterprising attitudes to find and pursue their livelihoods, training all of them in full- scale programmes for entrepreneurship development is an inefficient use of resources including time. Thus, what is needed is for all school leavers to go out into the world having been exposed to some basic values about being enterprising, preferably within the school system. This involves moving from a hidden curriculum of entrepreneurship to a formalised and structured course. The authors further argued that when such a concept is adequately implemented within the school system it becomes easier to acquire the basic enterprising values and attitudes that will help improve their livelihood

Ranasinghe (1996) argues that it is within this socio-culture milieu [within the education system] that youth make decisions on what training they will engage in and what career options they will consider. Adding to that Gunatilaka et al (2010) asserts that enhancing achievement and planning values especially opportunity seeking, innovation, information seeking and planning would increase the life chances of youth.

\section{Traditional Business Education versus Entrepreneurship Education}

Vesper and McMullan (1998:9) mentioned that traditional business education with the provision of skills needed to understand the function is to generate more quickly a greater variety of different ideas for how to exploit a business opportunity and the ability to project a more extensive sequence of action for entering business.

On the other hand, entrepreneurship education is defined as the structured formal conveyance of entrepreneurial competencies, which in turn refer to the concepts, skills and mental awareness used by individuals during the process of starting and developing their growth-oriented ventures. The reference to growth-oriented ventures made in this definition is noteworthy for education and training purposes as it allows for the differentiation of self-employment from entrepreneurship.

While all entrepreneurs are self-employed, not all self-employed persons are entrepreneurs (Garavan \& O'Cinneide, 1994). The emphasis is on formalising entrepreneurship education rather than leaving it for the hidden curricula, it may not be covered there, or it may be more confusing as there is lack of structure.

To assess the strength and weaknesses of current programs available to youth, a two prolonged strategic approach to youth entrepreneurship is imperative. According to Vodopivec (2010), the first component would promote an enterprise culture among all youth within and outside the school system, focusing on socio-culture aspects. The second 
component would improve entrepreneurship training and the enabling environment for those youth who wish to become entrepreneurs, focusing on economic, regulatory, and socio-culture aspects. A more rigorous approach to monitoring, evaluation, and impact assessment needs to be the cornerstone of such a strategy.

\section{How to Ensure Continued Commitment to the Promotion of Entrepreneurship Education?}

For the entrepreneurship to work effectively for school leaver, the authorities must promote an enterprise culture among the school goers. Mayer (2010) argues that there are four core values message needed to be conveyed to youth through the school and vocational training systems, as well as through social marketing campaigning. The value of being enterprising (opportunity and information seeking, creative and innovative, self-confident, and persistent); the value of business as a respectable option for a livelihood, the value of training and planning to run a successful enterprise and finally the value of operating a socially responsible enterprise to help one's family, village and region. Acquaintance with these values will bring confidence in high school students and therefore creating a greater likelihood of engaging in entrepreneurship.

A framework for policy development should be supporting the entrepreneurship education in the region and at national level. This would demand political support for entrepreneurship education and require the establishment of stakeholder groups that will set targets that entrepreneurship education should teach. Furthermore the assessment of entrepreneurship education activities should also be monitored in a co-coordinated manner (Sathorar, 2009)

Teaching support through training in entrepreneurship becomes essential, teachers should also be informed about national curriculum reforms and innovative methods should be adopted to train teachers (Sathorar 2009). Sharing of knowledge and techniques through the establishment of best practice schemes should be encouraged as well as the mobility of teachers across South Africa should also be encouraged. Teachers are central to any form of formal education, through their adaptation to changes in curricula and the interpretation of the educational material linking to relevant current examples to further understanding of the learners. Support to education establishment will also be required. This would involve better integration of entrepreneurship programs and activities into the established curriculum. It would require the support of the use of practice based pedagogical tools whereby students are involved in concrete enterprise projects.

Sathorar (2009) further argues that students should also be allowed to become involved in existing companies through holiday jobs as this will enhance their experience. The policy makers should build links and open education to the outside world to entail creating learning communities with the mission of fostering entrepreneurial mindsets. The involvement of private partners in education for entrepreneurship through funding of projects as well as providing role models for guidance and sharing of experience.

Having reviewed literature on entrepreneurship education and identified that its formalisation varies from country to country: it is important to analyse if entrepreneurship education is available in South African High schools. Since hidden curricula can be able to cover up for the lack of formalisation of some form of education, the role of teachers, parents, peers, relatives among others in educating high school pupils on entrepreneurship will be analysed.

\section{Methodology}

Descriptive research in this study established the Entrepreneurial awareness among high school leavers in Buffalo City Metropolitan Municipality. In this study, the evaluation of Entrepreneurial awareness followed both quantitative and qualitative approaches.

In order to obtain data for analysis primary data collection methods were used. Self-administered questionnaires were used as the instruments to collect primary data from the target population. The respective schools authorities were approached to get permission to conduct the survey with consent given on the proper timing. Likert scales predominant the instrument, coupled with dichotomous questions.

For the purpose of this study the following working definitions as per GEM (2008) report suffice:

Entrepreneurship education is the building of knowledge and skills either "about" or "for the purpose of" entrepreneurship generally, as part of recognized education programs at primary, secondary or tertiary-level educational institutions.

Entrepreneurship training is the building of knowledge and skills in preparation for starting a business.

Formal training includes any course that is part of an official education program, whether compulsory or voluntary. This includes primary or secondary education and tertiary-level certificate, diploma or degree programs.

Informal training operates outside formal programs, for example, non-credit bearing courses at a university, local 
business organization or a government agency.

More focus is on entrepreneurship education over entrepreneurship training, based on the target group of this study, the high school learners and the form/ content of the education that we need to test its presence. It is about awareness of entrepreneurship knowledge rather than about starting businesses.

\section{Population and Sample}

There are 87 high schools in Buffalo City Municipal area, as of 2009, (Kopolo, 2009). This research will be conducted in six high schools which fall under this area. For confidentiality the schools will be referred to using their former classification. First two schools are from the multi-racial, English speaking, ex model C schools, situated in fairly wealthy suburbs and mainly attract learners from middle to upper socio-economic income families. The second pair of schools is from townships in lower to middle socio-economic income families. The last pair is a formerly Coloured/Indian school. This analysis will also assist in inferring if past school set up has an influence on the presence or absence of entrepreneurial course. Former model $\mathrm{C}$ schools will be expected to be having an upper hand in this context.

This exercise attempted to provide the major variations in responses with regards to the learner's exposure to entrepreneurship knowledge at high school level (grade 7 to 12). This also attempt to measure the different problems which are experienced in such schools in as far as entrepreneurship education (or knowledge dissemination) is concerned.

The research study made use of simple random sampling method which is a probability sampling method and 25 learners per school were targeted giving a total sample of 150 respondents in total.

\section{Results and Discussions}

\subsection{Demographics}

\section{Gender}

\begin{tabular}{|c|c|c|c|c|c|}
\hline & Frequency & Percent & Valid Percent & Cumulative Percent \\
\hline \multirow{3}{*}{ Valid } & female & 89 & 59.3 & 59.3 & 59.3 \\
\hline & male & 61 & 40.7 & 40.7 & 100.0 \\
\hline & Total & 150 & 100.0 & 100.0 & \\
\hline
\end{tabular}

Educational level

\begin{tabular}{|l|c|c|c|c|}
\hline & Frequency & Percent & Valid Percent & Cumulative Percent \\
\hline & 2 & 1.3 & 1.3 & 1.3 \\
grade 10 & 38 & 25.3 & 25.3 & 26.7 \\
grade 11 & 69 & 46.0 & 46.0 & 72.7 \\
Valid grade 12 & 4 & 2.7 & 2.7 & 75.3 \\
grade 7 & 1 & .7 & .7 & 76.0 \\
grade 8 & 3 & 2.0 & 2.0 & 78.0 \\
grade 9 & 33 & 22.0 & 22.0 & 100.0 \\
Total & 150 & 100.0 & 100.0 & \\
\hline
\end{tabular}

Table 1. Race

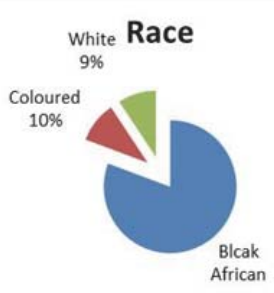


Overall, $81 \%$ of the respondents were black. This indicates the infiltration of former model schools by black students. This is a result of the independence and effort to break away racial classes that were created by Apartheid regime. Coloureds were $10 \%$ while the remainder represented white student respondents.

$59.3 \%$ of the respondents were female will the remainder are male students. On the other hand, the majority of respondents are Grade 11 learners (46\%) of the 148 pupils who indicated their grade level, followed by Grade 10s at $26 \%$ and the least were Grade $7 \mathrm{~s}$ at $1 \%$.

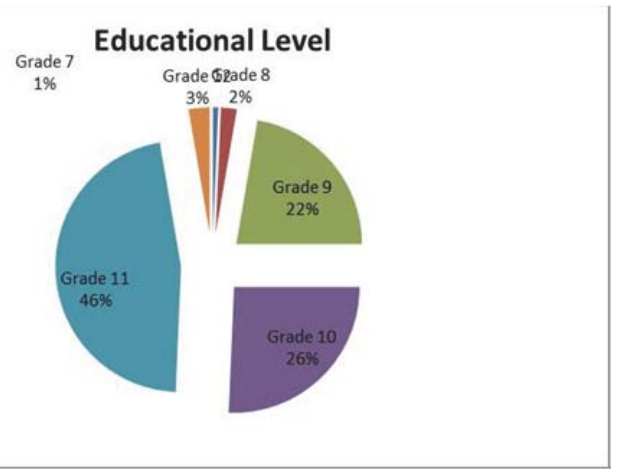

The share of each grade in the sample was not given weight during sampling as the main focus was to get high school students (Grade 7 to 12) and a convenient sampling technique applied

\subsection{Is Entrepreneurship taught in high schools?}

Table 2. Presence of entrepreneurship course is entrepreneurship taught at your School

\begin{tabular}{|cc|c|c|c|c|}
\hline & Frequency & Percent & Valid Percent & Cumulative Percent \\
\hline \multirow{4}{*}{ Valid } & 1 & .7 & .7 & .7 \\
& & 19 & 12.7 & 12.7 & 13.3 \\
& no & 19 & 86.7 & 100.0 \\
& yes & 130 & 86.7 & 86.7 & \\
& Total & 150 & 100.0 & 100.0 & \\
\hline
\end{tabular}

This table indicates that $86.7 \%$ respondents indicated that entrepreneurship is taught at their schools and $12.7 \%$ indicated the contrary, with one respondent to giving a response to that question. Since those who responded negative to this question are less than 25 (the total number of respondents targeted per school) the respondents might have misinterpreted the question and answered yes for entrepreneurship topic lessons under courses as business studies. Such topics are not covering extensively entrepreneurship education, though they help inform the learners, specific course for entrepreneurship education will be the best to fully acquaint the learners.

Table 3. Content with the Entrepreneurship course content- cross tabulation ENTRT * CONT Crosstabulation

\begin{tabular}{|c|c|c|c|c|c|c|}
\hline \multicolumn{7}{|c|}{ Count } \\
\hline & & & \multicolumn{3}{|c|}{ CONT } & \multirow{2}{*}{ Tota } \\
\hline & & & & no & yes & \\
\hline \multirow{4}{*}{ ENTRT } & & & 1 & 0 & 0 & 1 \\
\hline & & no & 14 & 1 & 4 & 19 \\
\hline & & yes & 3 & 9 & 118 & 130 \\
\hline & Total & & 18 & 10 & 122 & 150 \\
\hline
\end{tabular}

118 of the respondents said that entrepreneurship is taught at their school and there are content with the content of the subject, while 9 are not content with the taught content. There might have been confusion with this question as 
unrealistically 4 respondents indicate that entrepreneurship is not taught at their school but they also responded that they are content with the course content.

Chi-Square Tests

\begin{tabular}{|l|c|c|c|}
\hline & Value & df & Asymp. Sig. (2-sided) \\
\hline Pearson Chi-Square & 87.736 & 4 & .000 \\
Likelihood Ratio & 60.464 & 4 & .000 \\
N of Valid Cases & 150 & & \\
\hline
\end{tabular}

a. 5 cells (55.6\%) have expected count less than 5 . The minimum expected count is .07 .

The Pearson chi-square here has a significance of .000, meaning that if there were no relation between entrepreneurship being taught and learners being content with the course content in the population, the probability of obtaining discrepancies as large as in the sample would be no greater than .0005 . A chi-square of zero would indicate perfect agreement and no relationship between the variables. The chi-square results are significant since $p<0.05$. The chisquare is a measure of the discrepancy between the observed cell counts and what we expect if the row and column variables were related.

11.3 Teachers, refer to/approach entrepreneurship with enthusiasm for job creation or as a substitute for students not obtaining employment after leaving school? Testing if entrepreneurship is included in the hidden curriculum.

Have you heard about entrepreneurship

\begin{tabular}{|ll|c|c|c|c|}
\hline & Frequency & Percent & Valid Percent & Cumulative Percent \\
\hline \multirow{4}{*}{ Valid } & & 1 & .7 & .7 & .7 \\
\cline { 2 - 5 } & 4 & 2.7 & 2.7 & 3.3 \\
& no & 4 & 96.7 & 96.7 & 100.0 \\
& yes & 145 & 100.0 & 100.0 & \\
\hline
\end{tabular}

Heard about entrepreneurship from:

\begin{tabular}{|c|c|c|c|c|c|}
\hline & Frequency & Percent & Valid Percent & Cumulative Percent \\
\hline & & 16 & 10.7 & 10.7 & 10.7 \\
\hline & parents & 11 & 7.3 & 7.3 & 18.0 \\
\hline & peers & 3 & 2.0 & 2.0 & 20.0 \\
\hline Valid & relatives & 3 & 2.0 & 2.0 & 22.0 \\
\hline & teacher & 116 & 77.3 & 77.3 & 99.3 \\
\hline & workshops & 1 & .7 & .7 & 100.0 \\
\hline & Total & 150 & 100.0 & 100.0 & \\
\hline
\end{tabular}

Who encourages you to start own business

\begin{tabular}{|l|c|c|c|c|}
\hline & Frequency & Percent & Valid Percent & Cumulative Percent \\
\hline & 30 & 20.0 & 20.0 & 20.0 \\
parents & 45 & 30.0 & 30.0 & 50.0 \\
valid & 17 & 11.3 & 11.3 & 61.3 \\
reers & 14 & 9.3 & 9.3 & 70.7 \\
teacher & 30 & 20.0 & 20.0 & 90.7 \\
workshops & 14 & 9.3 & 9.3 & 100.0 \\
Total & 150 & 100.0 & 100.0 & \\
\hline
\end{tabular}

Statistics

\begin{tabular}{|cc|c|c|c|c|}
\hline & $\begin{array}{c}\text { never discuss } \\
\text { entrepreneurship with: }\end{array}$ & $\begin{array}{c}\text { rarely discuss } \\
\text { entrepreneurship with: }\end{array}$ & $\begin{array}{c}\text { sometimes discuss } \\
\text { entrepreneurship with }\end{array}$ & $\begin{array}{c}\text { regularly discuss } \\
\text { entrepreneurshp with }\end{array}$ \\
\hline \multirow{2}{*}{ N $\quad \begin{array}{c}\text { Valid } \\
\text { nissing }\end{array}$} & 150 & 150 & 150 & 150 \\
& 0 & 0 & 0 & 0 \\
\hline
\end{tabular}


Never discuss entrepreneurship with:

\begin{tabular}{|l|c|c|c|c|}
\hline & Frequency & Percent & Valid Percent & Cumulative Percent \\
\hline & 68 & 45.3 & 45.3 & 45.3 \\
Nalid & 3 & 2.0 & 2.0 & 47.3 \\
other & 7 & 4.7 & 4.7 & 52.0 \\
parents & 16 & 10.7 & 10.7 & 62.7 \\
peers & 6 & 4.0 & 4.0 & 66.7 \\
relatives & 23 & 15.3 & 15.3 & 82.0 \\
teachers & 27 & 18.0 & 18.0 & 100.0 \\
workshops & 150 & 100.0 & 100.0 & \\
Total & & & & \\
\hline
\end{tabular}

Rarely discuss entrepreneurship with:

\begin{tabular}{|l|c|c|c|c|}
\hline & Frequency & Percent & Valid Percent & Cumulative Percent \\
\hline & 56 & 37.3 & 37.3 & 37.3 \\
other & 1 & .7 & .7 & 38.0 \\
palid & 21 & 14.0 & 14.0 & 52.0 \\
peers & 21 & 14.0 & 14.0 & 66.0 \\
relatives & 15 & 10.0 & 10.0 & 76.0 \\
teachers & 30 & 20.0 & 20.0 & 96.0 \\
workshops & 6 & 4.0 & 4.0 & 100.0 \\
Total & 150 & 100.0 & 100.0 & \\
\hline
\end{tabular}

Sometimes discuss entrepreneurship with

\begin{tabular}{|l|c|c|c|c|}
\hline & Frequency & Percent & Valid Percent & Cumulative Percent \\
\hline & 36 & 24.0 & 24.0 & 24.0 \\
parents & 37 & 24.7 & 24.7 & 48.7 \\
peers & 13 & 8.7 & 8.7 & 57.3 \\
Valid relatives & 21 & 14.0 & 14.0 & 71.3 \\
& 39 & 26.0 & 26.0 & 97.3 \\
teachers & 4 & 2.7 & 2.7 & 100.0 \\
workshops & 150 & 100.0 & 100.0 & \\
Total & \multicolumn{3}{|c}{} \\
\hline
\end{tabular}

Regularly discuss entrepreneurshp with

\begin{tabular}{|l|c|c|c|c|}
\hline & Frequency & Percent & Valid Percent & Cumulative Percent \\
\hline & 68 & 45.3 & 45.3 & 45.3 \\
parents & 15 & 10.0 & 10.0 & 55.3 \\
veers & 26 & 17.3 & 17.3 & 72.7 \\
Valid & 15 & 10.0 & 10.0 & 82.7 \\
relatives & 22 & 14.7 & 14.7 & 97.3 \\
teachers & 4 & 2.7 & 2.7 & 100.0 \\
workshops & 150 & 100.0 & 100.0 & \\
Total & & & & \\
\hline
\end{tabular}

There was $100 \%$ response rate for the variable. $97 \%$ of the learners have heard about entrepreneurship before and the remaining responded negatively to the question.

From this study teachers have been identified as the greatest source of entrepreneurship information. Even if in some schools entrepreneurship is not formally taught, about $77 \%$ of the respondents have heard about entrepreneurship from their teachers, compared to $7.3 \%$ from parents, $2 \%$ from peers as well as from relatives. However, $10.7 \%$ of the respondents did not provide answer to this question. Nonetheless the contribution by teachers to entrepreneurship education is remarkable here.

Topping the source of encouragement to start business among high school students are parents and teachers totalling 50\%, that is (30\%) and (20\%) respectively. The concept of hidden curricula for entrepreneurship is therefore alive 
within these high schools. Workshops and relatives also scored the least in this category (both at $14 \%$ each). This maybe a result of children living most of their time with parents (not very mobile as adults) and that few workshops are being organised targeting high school kids. Education of teachers and parents on entrepreneurship will likely have a ripple effect down to the high school going population.

Augmenting the previous responses, $18 \%$ of the respondents indicated that they have never discussed entrepreneurship at workshops. This aspect's scoring of the highest of all responses in his category point to the fact that there is a great lack of workshops targeting high school students. Teachers received the second largest score, which reflects that, even though teachers are the greatest source of entrepreneurial knowledge to these students, the information is mainly one way, from teacher to pupils, no discussion is promoted. Though passing the information y teachers is highly welcome, absence of discussion will reduce the knowledge accumulation and aspect of clearing doubts and confusion among learners as they do not have a chance of saying their views or asking follow up questions.

Interestingly, high schools students discuss more about entrepreneurship among themselves (17.3\%), with teachers (14.7\%), and parents and relatives (10\% apiece). For the students to benefit more from the discussions, especially with peers, informative workshops targeting high school students (as they discuss entrepreneurship among themselves) is high important in order to inform their discussion. Effective workshops for this target group will result in the correct information spreading fast. It will be disastrous if these students discuss about entrepreneurship without much knowledge about it, a negative perception by a few vocal can easily filter through the group.

\subsection{Students will be more inclined to become entrepreneurs if entrepreneurship was taught at school?}

\section{School classification * is entrepreneurship taught at your school * first career options Crosstabulation} Count

\begin{tabular}{|c|c|c|c|c|c|c|}
\hline & \multirow{2}{*}{ first career options } & & \multicolumn{3}{|c|}{ is entrepreneurship taught at your school } & \multirow{2}{*}{ Total } \\
\hline & & & & no & yes & \\
\hline & \multirow{3}{*}{ school classification } & formerK & 1 & 10 & 13 & 24 \\
\hline & & formerMC & 0 & 0 & 14 & 14 \\
\hline & & formerT & 0 & 2 & 14 & 16 \\
\hline & \multicolumn{2}{|c|}{ Total } & 1 & 12 & 41 & 54 \\
\hline \multirow{4}{*}{ corporate job } & \multirow{3}{*}{ school classification } & formerK & & 4 & 6 & 10 \\
\hline & & formerMC & & 0 & 18 & 18 \\
\hline & & formerT & & 1 & 13 & 14 \\
\hline & \multicolumn{2}{|c|}{ Total } & & 5 & 37 & 42 \\
\hline \multirow{4}{*}{ entrepreneur } & \multirow{3}{*}{ school classification } & formerk & & 1 & 15 & 16 \\
\hline & & formerMC & & 0 & 19 & 19 \\
\hline & & formerT & & 1 & 18 & 19 \\
\hline & Total & & & 2 & 52 & 54 \\
\hline \multirow{4}{*}{ Total } & \multirow{3}{*}{ school classification } & formerK & 1 & 15 & 34 & 50 \\
\hline & & formerMC & 0 & 0 & 51 & 51 \\
\hline & & formerT & 0 & 4 & 45 & 49 \\
\hline & Tota & & 1 & 19 & 130 & 150 \\
\hline
\end{tabular}

Chi-Square Tests

\begin{tabular}{|ll|l|l|l|}
\hline first career options & Value & df & Asymp. Sig. (2-sided) \\
\hline & Pearson Chi-Square & $11.973^{\mathrm{a}}$ & 4 & .018 \\
& Likelihood Ratio & 14.797 & 4 & .005 \\
& N of Valid Cases & 54 & & \\
\hline corporate job & Pearson Chi-Square & $10.262^{\mathrm{b}}$ & 2 & .006 \\
& Likelihood Ratio & 9.997 & 2 & .007 \\
& N of Valid Cases & 42 & & \\
\hline entrepreneur & Pearson Chi-Square & $1.151^{\mathrm{c}}$ & 2 & .562 \\
& Likelihood Ratio & 1.792 & 2 & .408 \\
& N of Valid Cases & 54 & & \\
\hline
\end{tabular}




\begin{tabular}{|c|c|c|c|c|}
\hline Total & $\begin{array}{l}\text { Pearson Chi-Square } \\
\text { Likelihood Ratio } \\
\mathrm{N} \text { of Valid Cases }\end{array}$ & $\begin{array}{l}24.312^{d} \\
27.866 \\
150\end{array}$ & $\begin{array}{l}4 \\
4\end{array}$ & $\begin{array}{l}.000 \\
.000\end{array}$ \\
\hline
\end{tabular}

a. 5 cells (55.6\%) have expected count less than 5 . The minimum expected count is . 26 .

b. 3 cells $(50.0 \%)$ have expected count less than 5 . The minimum expected count is 1.19 .

c. 3 cells $(50.0 \%)$ have expected count less than 5 . The minimum expected count is .59 .

d. 3 cells (33.3\%) have expected count less than 5 . The minimum expected count is 33 .

\section{Symmetric Measures ${ }^{\mathrm{a}}$}

\begin{tabular}{|c|c|c|}
\hline \multicolumn{2}{|c|}{ first career options } & Value \\
\hline & $\mathrm{N}$ of Valid Cases & 54 \\
\hline corporate job & $\mathrm{N}$ of Valid Cases & 42 \\
\hline entrepreneur & $\mathrm{N}$ of Valid Cases & 54 \\
\hline Total & $\mathrm{N}$ of Valid Cases & 150 \\
\hline
\end{tabular}

a. Correlation statistics are available for numeric data only.

There are variations in response to questions like; is entrepreneurship taught at your school and the first career choice (between entrepreneurship and corporate job) across (former) school classifications. 52 compared to 37 indicated that entrepreneurship is taught at their school and their first career choice is to become entrepreneurs. The knowledge gained from the entrepreneurship lessons could have boosted the confidence. The 37 selected corporate job as their first career choice.

Former Coloured schools have interesting results in this regard. Of those who indicated that entrepreneurship is taught at their school grade (34), 6 prefer corporate job as first career choice and 15 prefer being entrepreneurs. 15 of the respondents indicated that entrepreneurship is not taught in their grade, and one did not respond to the question, to give a total of 50 respondents targeted for this particular school class.

Of interest again is the fact that 51 of the respondents from former model $\mathrm{C}$ schools indicated that entrepreneurship is taught at their school grade. It implies that at former model $\mathrm{C}$ schools entrepreneurship lessons (under business studies, workshops for example) start at least from grade 7. This finding speak well to the GEW report findings reported on page 2, that entrepreneurship activity is high among whites than blacks or Coloureds, as the schools were dominated by whites. Former model $\mathrm{C}$ schools were predominantly for whites and their system of including entrepreneurship in the curricula may have contributed to such high entrepreneurship activity captured in the said report. In fact, former model $\mathrm{C}$ schools are characterised by multi-racial, English speaking, situated in fairly wealthy suburbs and mainly attract learners from middle to upper socio-economic income families. The learners may be exposed to entrepreneurship activities within the family and through various forms of media outreach programmes, for example MyBiz sponsored by Nedbank on eTV station. The results correspond to the observation by Kourilsky (1995) that youngsters are observing in dismay as corporation after corporation downsizes its workforce and drastically rewrites (if not abandons) the assumptions that used to constitute the unwritten contract between the long-term employee and the corporate employer.However the number for those choosing cooperate job or entrepreneurship as career choice is almost equal, 18 and 19 respectively. The Pearson chi-square is significant with totals $(.000<.05)$ but not significant at sublevels because the $p$ value $(.018, .06$ and .562$)$ are all greater than 0.05 . More advance techniques are a called to further test the significance of the interaction, however for this study no such test are carried out.

\subsection{Students feel entrepreneurship must be included in high school curriculum.}

Should entrepreneurship education be formalised

\begin{tabular}{|c|c|c|c|c|c|}
\hline & & Frequency & Percent & Valid Percent & Cumulative Percent \\
\hline & & 3 & 2.0 & 2.0 & 2.0 \\
\hline & no & 12 & 8.0 & 8.0 & 10.0 \\
\hline & yes & 135 & 90.0 & 90.0 & 100.0 \\
\hline & Total & 150 & 100.0 & 100.0 & \\
\hline
\end{tabular}


Should entrepreneurship be a stand alone subject

\begin{tabular}{|c|c|c|c|c|c|}
\hline & & Frequency & Percent & Valid Percent & Cumulative Percent \\
\hline \multirow{4}{*}{ Valid } & & 5 & 3.3 & 3.3 & 3.3 \\
\hline & no & 19 & 12.7 & 12.7 & 16.0 \\
\hline & yes & 126 & 84.0 & 84.0 & 100.0 \\
\hline & Total & 150 & 100.0 & 100.0 & \\
\hline
\end{tabular}

$90 \%$ of the respondents feel that entrepreneurship must be formalised in high schools, with $8 \%$ saying no to the posed question and $2 \%$ failing to respond. In most schools it has been observed that entrepreneurship is taught under Business studies subject, therefore it's a component of another course not really a stand along subject. When asked if entrepreneurship should be a "stand alone" subject, $84 \%$ said yes and $12.7 \%$ responded negatively. This is a shout from the learners that they need to learn more about entrepreneurship (starting businesses, identifying opportunities and strategies to service the competition) and they believe it is good for them. The greatest attribute any society could boast of, is a learning population- a population willing and available to learn.

\section{Conclusions and Recommendations}

Entrepreneurship education is present in high schools based Buffalo City Municipality, albeit informally. From observation entrepreneurship is a topic under business studies; therefore most learners access it from through that.

Teachers are playing a prominent role in disseminating information about entrepreneurship to high school learners. This is a great testimony to the role of hidden curricula. It is crucial then that teachers receive entrepreneurship education so that they will be able to inform well the learners. This applies to parents who also engage high school students in entrepreneurship discussions. Therefore parents should also be well equipped with entrepreneurship knowledge. Parents and teachers play a significant and central role in the development of children, the best do be done in this regard is to train them to be able to be trainers themselves (even if not formal training to be extended to high school students, it is crucial that the information disseminators be trained formally).

Entrepreneurship should gain more academic esteem and should raise the awareness of the role of enterprises and entrepreneurs in society. This could be done by disseminating in schools material with success stories of young entrepreneurs. The association of students with real companies and business people should be encouraged and the natural initiatives of student associations should be supported. As well the involvement of alumni in school and class activities should be encouraged and students could issue with certificates acknowledging their participation in the program and their successful acquisition of entrepreneurial skills. The certificate will only be issued if the student meets the set criteria of assessment.

The awareness can also be improved by engaging on community activities for example launching awareness campaigns at regional and national level ensuring that entrepreneurship is understood. It is also important to celebrate successful entrepreneurship education activities by establishing awards in recognition of these achievements.

There is also a need to promote entrepreneurship training; a pathway to business concept needs to be institutionalized within and outside the school system. This is to ensure that school leavers at all levels, as well as graduates of vocational training institutions and universities, can access training at appropriate points in their lives. A social safety net for young entrepreneurs, such as a security fund, to reduce risk, has been initiated in other countries.

\section{References}

Alberti F, Sciascia S, Poli A (2004). Entrepreneurship Education: Notes on an On-going debate. Proceedings of the 14th Annual IntEnt Conference. University of Napoli Federico II, Italy. 4-7 July.

Brijlal P, Isaacs E, Visser K, Friedrich C (2007). Entrepreneurship Education and Training at the Further Education and Training (FET) level in South Africa. South African Journal of Education

Davies TA (2001). Entrepreneurship Development in South Africa: Redefining the role of Tertiary institutions in reconfigured Higher Education System. South African Journal of higher Education, 15(1)

Garavan TN, O'Cinneide B (1994). Entrepreneurship Education and Training - programmes: A review an evaluation -Part 2. Journal of European Industrial Training 18(11): 13-22

GEM (2010). (Martínez A.C, Levie, J., Kelley, D.J., Sæmundsson, R.J., Schøtt, T., and the Global Entrepreneurship Research Association (GERA)) A Global Perspective on Entrepreneurship Education and Training; in Global entrepreneurship Monitor Special Report

Gouws E (1998). Economic literacy and Entrepreneurship: Study Guide 2 for PST303-4. Pretoria: University of South Africa. 
Gunatilaka R, Mayer M, Millan V( 2010). The Challenge of Youth Employment in Sri Lanka .World Bank.

Higgins D, Elliot C (2010). Learning to make sense: What Works in Entrepreneurship Educational? Journal of European Industrial Training, Vol. 35 No. 4, 2011 pp. 345-367; Emarald.

Hindle K (2007). Formalizing the concept of entrepreneurial capacity. Paper presented at the Refereed Proceedings of the 2007 ICSB World Conference, Finland: Turku School of Economics.

Honig B (2004). Entrepreneurship Education: Toward a Model of Contingency-Based Business Planning. Academy of Management Learning and Education 3 (3): 258-273.

International Alert (2005). Peace through Profit: Sri Lanka Perspective on Corporate Social Responsibility, Colombo.

Kent C (1990). Entrepreneurship Education: Current Developments. New York: Quorum

King K (1989). Education for Employment and Self- employment- intervention in developing countries: past experience and present prognosis. A paper in the Seminar on Education and Training for Employment in the SADCC countries, Victoria Falls, Zimbabwe, 24-28 April.

Kopolo L (2009). Assessing the Impact of Qualified Mathematics and Science Teachers in The Buffalo City Area; Masters Thesis in Business Administration at the Nelson Mandela Metropolitan University December 2009

Kourilsky (1995). Entrepreneurship Education: Opportunity In Search Of Curriculum; Published in Business Education Forum, October 1995

Mabunda NP (2002). The Role of the School in Preparing School Leavers for Self-employment. University of South Africa.

Mauchi et al. (2011). Entrepreneurship education lessons: a case of Zimbabwean tertiary education institutions; Educational Research (ISSN: 2141-5161) Vol. 2(7) pp. 1306-1311 July 2011; Available online@ http://www.interesjournals.org/ER

Mayer EL (2010). El Fomento de la Creation de Empresas desde la Universidad Mexicana. El Caso de la Universidad Autónoma en Tamaulipas. Doctoral Thesis. Universitá Autónoma de Barcelona

Mwangi SM (2011). The Contribution of Entrepreneurship Education Course in Enhancing Management Skills of Informal Entrepreneurs; Journal of Education and Vocational Research; Vol. 2, No. 3, pp. 86-92, Sep 2011 (ISSN 2221-2590)

Niyonkuru R (2005). Entrepreneurship Education at Tertiary Institutions in Rwanda: a Situation Analysis, Master's Thesis, University of the Western Cape

Organisation for Economic Co-operation and Development (2005). OECD SME and Entrepreneurship Outlook 2005. OECD

Ranasinghe S (1996). Entrepreneurship Education and Training in Sri Lanka." Sri Lankan Journal of Management 1 (3): 262-77

Rayne RA (1982). The Entrepreneur: An Educational Challenge. Search, 13(9-10): 235-241.

Sathorar H (2010). Assessing Entrepreneurship Education at Secondary Schools in the NMBM. Nelson Mandela Metropolitan University

Summit Consulting (2009). Toward Effective Education of Innovative Entrepreneurs in Small Business: Initial Results from a Survey of College Students and Graduates. Washington, DC: Small Business Administration Office of Advocacy

Vesper KH, McMullan WE (1988). Entrepreneurship: today courses, tomorrow degrees? Entrepreneurship Theory and Practice, 13 (1), 7-13.

Wennekers S, and Thurik R (1999). Linking entrepreneurship and economic growth. Small Business Economics 13: 27-55.

World Economic Forum (2009). Educating the Next Wave of Entrepreneurs: Unlocking Entrepreneurial Capabilities to Meet the Global Challenges of the $21^{\text {st }}$ Century: A Report of the Global Education Initiative. Switzerland: World Economic Forum.

Zeithaml CP, Rice GH (1987). Entrepreneurship/small business education in American universities. Journal of Small Business Management, 25(1), 44-50. 